\title{
Beyond leptin: emerging candidates for the integration of metabolic and reproductive function during negative energy balance
}

\section{Cadence True, Kevin L. Grove and M. Susan Smith*}

Division of Neuroscience, Oregon National Primate Research Center, Oregon Health and Science University, Beaverton, OR, USA

\author{
Edited by: \\ Jennifer Wootton Hill, University of \\ Toledo College of Medicine, USA \\ Reviewed by: \\ Sebastien G Bouret, University of \\ Southern California, USA \\ Tamara Castañeda, German Diabetes \\ Center, Germany \\ *Correspondence: \\ M. Susan Smith, Division of \\ Neuroscience, Oregon National \\ Primate Research Center, Oregon \\ Health and Science University, 505 \\ NW 185th Avenue, Beaverton, OR \\ 97006, USA. \\ e-mail:smithsu@ohsu.edu
}

\begin{abstract}
Reproductive status is tightly coupled to metabolic state in females, and ovarian cycling in mammals is halted when energy output exceeds energy input, a metabolic condition known as negative energy balance. This inhibition of reproductive function during negative energy balance occurs due to suppression of gonadotropin-releasing hormone (GnRH) release in the hypothalamus. The $\mathrm{GnRH}$ secretagogue kisspeptin is also inhibited during negative energy balance, indicating that inhibition of reproductive neuroendocrine circuits may occur upstream of $\mathrm{GnRH}$ itself. Understanding the metabolic signals responsible for the inhibition of reproductive pathways has been a compelling research focus for many years. A predominant theory in the field is that the status of energy balance is conveyed to reproductive neuroendocrine circuits via the adipocyte hormone leptin. Leptin is stimulatory for $\mathrm{GnRH}$ release and lower levels of leptin during negative energy balance are believed to result in decreased stimulatory drive for $\mathrm{GnRH}$ cells. However, recent evidence found that restoring leptin to physiological levels did not restore $\mathrm{GnRH}$ function in three different models of negative energy balance. This suggests that although leptin may be an important permissive signal for reproductive function as indicated by many years of research, factors other than leptin must critically contribute to negative energy balance-induced reproductive inhibition. This review will focus on emerging candidates for the integration of metabolic status and reproductive function during negative energy balance.
\end{abstract}

Keywords: leptin, GnRH, Kisspeptin, GnIH

\section{INTRODUCTION}

Metabolic status is a known regulator of reproductive function, with both over- and under-nutrition resulting in reproductive dysfunction. In female mammals, this is frequently observed as a disruption of reproductive cycling leading to anovulation. Cyclic reproductive function is controlled by the hypothalamicpituitary-gonadal axis, in which gonadotropin-releasing hormone ( $\mathrm{GnRH})$ is released from the hypothalamus, causing the release of the gonadotropins luteinizing hormone (LH) and folliclestimulating hormone (FSH) from the pituitary followed by estrogen and progesterone release from the ovary. Disruptions at any level in this pathway can result in acyclicity. Despite years of intense study in this field, many key questions remain unanswered in our understanding of how changes in metabolic status result in disruption of the hypothalamic-pituitary-gonadal axis.

One well-studied candidate for the integration of metabolic and reproductive function is the adipocyte hormone leptin (for reviews see Clarke and Henry, 1999; Cunningham et al., 1999; Bluher and Mantzoros, 2007; Tena-Sempere, 2007; Hill et al., 2008). Circulating leptin levels directly correlate to adipose stores and are highly sensitive to changes in metabolic status, making it an ideal candidate to signal changes in energy balance to central and peripheral systems (Maffei et al., 1995; Blache et al., 2000). Within the hypothalamic-pituitary-gonadal axis, there is evidence that leptin acts to stimulate GnRH release through an intermediate cell population, rather than through direct actions on $\mathrm{GnRH}$ neurons (Yu et al., 1997; Watanobe, 2002; Quennell et al., 2009). The candidates for this intermediate cell population include arcuate nucleus kisspeptin cells (discussed below) and glutamate cells in the ventral premammillary nucleus. The latter population has only been described recently for its role in leptin's reproductive regulation, based on the high number of cells expressing leptin receptors in this area and direct projections from these cells to GnRH neurons (Leshan et al., 2009; Louis et al., 2011; Patterson et al., 2011). In addition to the morphological evidence, in vivo studies found that lesions to the ventral premammillary nucleus prevented leptininduced-LH stimulation (Donato et al., 2009, 2011). Given these results, glutamate cells in the ventral premammillary nucleus are clearly exciting new candidates in understanding leptin's role in reproduction.

A large portion of research has focused on the regulatory influence of leptin for the initiation of puberty. There is evidence of a developmental increase in leptin levels between postnatal day 20 and 40 in the rat, the latter date corresponding to vaginal opening and followed soon after by the first estrus cycle (Gruaz et al., 1998). Similar results have been found in humans, suggesting leptin may be critical to stimulate normal pubertal development (Mantzoros et al., 1997). There is an abundance of data to support 
this hypothesis, most notably the evidence that leptin deficient ob/ob mice do not undergo puberty and are infertile, a phenotype rescued with exogenous leptin treatment (Ingalls et al., 1950; Swerdloff et al., 1976; Barash et al., 1996; Chehab et al., 1996). Zucker Fatty Rats lacking a functional leptin receptor also have delayed pubertal development and reduced LH levels (Zucker and Zucker, 1961; Saiduddin et al., 1973; Phillips et al., 1996; Todd et al., 2003). These transgenic studies recapitulate findings in humans in which genetic mutations in the leptin signaling system have been reported to result in both dramatically delayed and absent pubertal development (Clement et al., 1998; Strobel et al., 1998). In addition, overexpression of leptin, or exogenous treatment of wild-type mice results in early onset of puberty in rodents (Ahima et al., 1997; Chehab et al., 1997). Given this evidence it is clear that leptin plays a critical role in signaling sufficient metabolic energy stores required for the initiation of $\mathrm{GnRH}$ release and puberty in rodents and humans. Notably, puberty in the non-human primate is not preceded by a rise in circulating leptin, suggesting other signals are responsible for the initiation of puberty in this species (Plant and Durrant, 1997).

\section{NEGATIVE ENERGY BALANCE-INDUCED ACYCLICITY AND HYPOLEPTINEMIA}

To understand the role of leptin for the integration of energy balance and reproductive function, investigators have relied in part on animal models of negative energy balance, where energy output exceeds energy input. Negative energy balance-induced reproductive acyclicity is a highly conserved phenomenon, present in all female mammals investigated to date. It is well understood that the halting of ovarian cycling in this case likely occurs through inhibition of $\mathrm{GnRH}$ release from the hypothalamus, since exogenous GnRH rescues cyclic reproductive function (Bronson, 1986; Bergendahl et al., 1991; Cameron and Nosbisch, 1991; Kile et al., 1991; Aloi et al., 1997). Given the proposed stimulatory role of leptin in GnRH release, the prevailing hypothesis in the field is that reproductive dysfunction during negative energy balance occurs due to hypoleptinemia and thus a decrease in stimulatory drive for GnRH release. This hypothesis is supported by multiple studies demonstrating that exogenous leptin treatment during fasting models of negative energy balance stimulates $\mathrm{GnRH}$ release as measured by circulating $\mathrm{LH}$ levels (Ahima et al., 1996; Nagatani et al., 1998, 2000). However, these studies used pharmacological doses of leptin that resulted in levels at least 50-fold higher than normal circulating levels (Ahima et al., 1996). Even with pharmacological doses of leptin replacement, Ahima et al. (1996) found only partial restoration of LH levels, suggesting a continued inhibitory source for $\mathrm{GnRH}$ release was still present. This latter finding indicates that while hypoleptinemia may play a role in suppression of $\mathrm{GnRH}$ during negative energy balance in rodents, other players are also likely involved.

Recent research suggests that metabolic signaling beyond leptin may also be critical for the reversal of GnRH inhibition upon exit from negative energy balance back to a normal metabolic state. Research from our lab examined the effects of restoring leptin to physiological levels during lactation, a naturally occurring condition of negative energy balance in which the energy requirement for milk production exceeds energy intake. Restoring leptin during mid-lactation had no effect to restore LH levels (Xu et al., 2009b). However, it could be argued that lactation is a complicated physiological model, with other known sources of GnRH inhibition (Brogan et al., 1999); therefore, it is possible that leptin's effects were masked by continued inhibitory inputs specific to lactation ( $\mathrm{Li}$ et al., 1999c). To test this hypothesis a long-term caloric restriction (CR) model was developed to mimic the duration and intensity of lactation-induced negative energy balance, but once again restoration of leptin to physiological levels did not normalize mean LH levels (True et al., 2011b). This data was in direct contrast to previous results; however, these earlier studies used a short-term fasting model of negative energy balance and also employed much higher pharmacological levels of leptin replacement (Ahima et al., 1996; Nagatani et al., 1998). To determine whether these discrepancies were due to the different models of negative energy balance or to the dose of leptin, leptin was replaced in a 48 hour fasting model to both physiological and pharmacological levels. Despite partial normalization of LH levels with the pharmacological dose of leptin, consistent with previous results (Ahima et al., 1996; Nagatani et al., 1998), restoration of physiological levels of leptin had no effect on fasting-suppressed LH levels (True et al., 2011b). Additional research arguing against a critical role for leptin in the restoration of LH upon exit from negative energy balance comes from the lean ewe model. Szymanski et al. (2007) demonstrated that when lean acyclic ewes are refed, LH levels rise quickly, and importantly this increase occurs prior to any increase in circulating leptin levels. Together, these studies confirm earlier indications that while hypoleptinemia may play a permissive role in negative energy balance-induced reproductive dysfunction it does not appear to be critical for GnRH inhibition (Smith et al., 2010b). It should be noted that physiological levels of leptin seem more effective at preventing LH inhibition in humans, pointing to important species differences in this field (Welt et al., 2004). In the rodent many other candidates involved in the integration of metabolic and reproductive function exist, and there are many reviews on the role of appetitive hormones and hypothalamic peptides in this process (Kalra and Kalra, 1996; Schioth and Watanobe, 2002; Smith and Grove, 2002; Fernandez-Fernandez et al., 2006; Garcia et al., 2007; Hill et al., 2008; Tena-Sempere, 2008; Smith et al., 2010b). The goal of this review is to highlight more recent and emerging candidates involved in $\mathrm{GnRH}$ regulation that also have ties to metabolic regulation, and discuss their potential roles during negative energy balance.

\section{INHIBITION OF KISSPEPTIN AS A CENTRAL MECHANISM OF GnRH INHIBITION}

It would be remiss to discuss regulation of GnRH release without mention of the neuropeptide kisspeptin (Kiss1). Kiss1 was found to be the endogenous ligand of an orphan receptor, g-protein coupled receptor 54 (GPR54), and is an extremely potent stimulator of GnRH release (Kotani et al., 2001; Muir et al., 2001; Ohtaki et al., 2001; Navarro et al., 2004; Thompson et al., 2004; Dumalska et al., 2008; Popa et al., 2008). Mutations in either the Kiss1 or GPR54 gene results in hypogonadotropic hypogonadism in humans, indicating Kiss 1 signaling is critical for reproductive function (de Roux et al., 2003; Seminara et al., 2003). Two major populations of 
Kiss1 neurons have been identified in several species, including the rodent, one in the arcuate nucleus and another in the anteroventral periventricular nucleus (AVPV). These two populations are thought to be involved in negative and positive steroid feedback of GnRH release, respectively (Smith et al., 2005a,b, 2006b; Dungan et al., 2006; Clarkson et al., 2008; Popa et al., 2008; Clarkson and Herbison, 2009). Interestingly, these two populations of Kiss1 neurons have different projections, with AVPV Kiss1 cells contacting GnRH cell bodies in the preoptic area and arcuate nucleus Kiss1 cells sending fibers to the median eminence, where they are in close contact with GnRH fibers (True et al., 2011a). Kiss1 appears to be regulated by metabolic conditions suggesting it may also be important for negative energy balance-induced GnRH suppression. In lactating and CR models Kiss1 levels are suppressed in both the arcuate nucleus and AVPV (Yamada et al., 2007; Xu et al., 2009b; True et al., 2011b). While studies reporting the effect of fasting on Kiss1 levels have been inconsistent, there are reports of inhibition in both nuclei in this model as well (Castellano et al., 2005; Luque et al., 2007; Forbes et al., 2009; Backholer et al., 2010). These results suggest that inhibition of GnRH release during negative energy balance may occur upstream at Kiss1 populations, which in turn results in decreased stimulatory drive for $\mathrm{GnRH}$ (Hill et al., 2008; Roa et al., 2008; Castellano et al., 2009, 2010).

Surprisingly, very little is known about afferent signals that regulate AVPV and arcuate nucleus Kiss1 cells. Numerous studies have found evidence for a stimulatory role of leptin for Kiss 1 expression (Castellano et al., 2006, 2010; Luque et al., 2007; Backholer et al., 2010). Double-label in situ hybridization found leptin receptor expression colocalized with arcuate nucleus Kiss1 cells in the mouse and sheep (Smith et al., 2006a; Backholer et al., 2010), and leptin treatment resulted in rapid depolarizations of arcuate nucleus Kiss 1 cells in guinea pigs, suggesting a direct regulatory relationship (Qiu et al., 2011). However, studies using the leptin receptor-green fluorescent protein (GFP) transgenic mice show virtually no colocalization of GFP with Kiss1-immunoreactivity (Louis et al., 2011). Further work in mice and rats has demonstrated a lack of pSTAT3, a signal transducer and activator of transcription stimulated by leptin receptor signaling, in Kiss 1 cells after treatment with high levels of leptin (Louis et al., 2011; Quennell et al., 2011; True et al., 2011b); however, it remains possible that leptin signaling in Kiss 1 cells may be through cascades not involved in gene transcription and PSTAT3 activation, as suggested by rapid electrophysiological responses (Qiu et al., 2011). Importantly, restoring leptin to physiological levels does not restore arcuate nucleus Kiss1 levels in either lactation or CR, suggesting hypoleptinemia may not be a required signal for arcuate nucleus Kiss1 inhibition during negative energy balance (Xu et al., 2009b; True et al., 2011b). Given the important role of Kiss1 in GnRH regulation, and its implicated involvement in negative energy balance, understanding the regulatory afferent inputs for Kiss 1 cells will be critical to our understanding of the integration of energy balance and reproduction.

\section{REGULATION OF NEUROKININ B AND DYNORPHIN AS A CENTRAL MECHANISM OF GnRH INHIBITION}

Arcuate nucleus Kiss1 cells also express the tachykinin neuropeptide, neurokinin B (NKB; Goodman et al., 2007; True et al., 2011a).
Similar to Kiss1, NKB also appears critical for development of reproductive function since mutations in the genes encoding $\mathrm{NKB}$ and the NKB receptor NK3, also result in hypogonadotropic hypogonadism in humans (Topaloglu et al., 2009). NKB levels are inhibited by estradiol in several species and there is strong evidence that NKB plays a role in negative steroid feedback (Rance and Young, 1991; Danzer et al., 1999; Goubillon et al., 2000; Pillon et al., 2003; Rance, 2009; Navarro et al., 2011). For many years results were inconsistent as to whether $\mathrm{NKB}$ was stimulatory or inhibitory for GnRH release (Sahu and Kalra, 1992; SandovalGuzman and Rance, 2004; Corander et al., 2010), but more recent evidence has supported a stimulatory role, consistent with reproductive dysfunction in humans with mutations in the NKB system (Billings et al., 2010; Ramaswamy et al., 2010; Wakabayashi et al., 2010; Navarro et al., 2011). There is evidence in the rat that NKB may directly stimulate $\mathrm{GnRH}$ release through fiber contacts in the external zone of the median eminence (Krajewski et al., 2005). In addition to direct regulation of GnRH cells, there is also evidence that $\mathrm{NKB}$ may indirectly regulate $\mathrm{GnRH}$ release through stimulating-autoregulatory actions on arcuate nucleus Kiss1/NKB cells (Navarro et al., 2009, 2011; Wakabayashi et al., 2010).

Our laboratory has investigated whether NKB may play a role in negative energy balance-induced inhibition of GnRH release. Real-time PCR analysis has demonstrated that arcuate nucleus NKB mRNA expression is decreased during lactation, and is also inhibited during severe 50\% CR (Xu et al., 2009b; True et al., 2011b). This is in contrast to a lack of inhibition during more moderate $40 \%$ CR and a 48 -h fast (True et al., 2011b). These findings suggest that arcuate nucleus NKB inhibition may be involved in more severe conditions of negative energy balance to shut off cyclic reproductive function. Similar to Kiss1, little is known about the upstream regulatory input for arcuate nucleus NKB expression, although work from our group found no evidence that leptin regulates $\mathrm{NKB}$ expression during negative energy balance (Xu et al., 2009b; True et al., 2011b). It is of interest to note that arcuate nucleus Kiss $1 / \mathrm{NKB}$ cells also express dynorphin, yet another neuropeptide involved in reproductive regulation (Burke et al., 2006; Goodman et al., 2007). Similar to NKB, dynorphin receptors are also found on arcuate nucleus Kiss1/NKB/dynorphin (KNDy) cells suggesting a potential autoregulatory action (Navarro et al., 2009). However, dynorphin is thought to be inhibitory for GnRH release and unlike NKB, dynorphin is not differentially regulated during negative energy balance (Schulz et al., 1981; Kinoshita et al., 1982; Leadem and Kalra, 1985; Xu et al., 2009b; True et al., 2011b). A similar example of juxtaposed coexpressing neuropeptides exists in the hypothalamic feeding cells containing $\alpha$-melanocyte-stimulating hormone and $\beta$-endorphin, which are stimulatory and inhibitory for food intake, respectively (Imura et al., 1985; Tsujii and Bray, 1989; Kim et al., 2000). It remains unclear how coexpression of these two counteracting neuropeptides may be coordinated to control food intake in the hypothalamus (Hughes et al., 1988). In the case of KNDy neurons it is tempting to speculate that differential expression of $\mathrm{NKB}$ and dynorphin may tightly regulate the release of Kiss1 into the median eminence. Furthermore, precisely timed Kiss1 release may be physiologically significant for the regulation of basal pulsatile GnRH release. 


\section{GONADOTROPIN-INHIBITORY HORMONE}

While Kiss1 and NKB are likely important stimulatory signals for $\mathrm{GnRH}$ and gonadotropin release, research over the past decade has uncovered a similarly important inhibitory signal aptly named gonadotropin-inhibitory hormone $(\mathrm{GnIH})$. GnIH was first isolated from avian brains and characterized by its ability to inhibit gonadotropin release from pituitary explants (Tsutsui et al., 2000). Over time the mammalian homolog termed RF-amide related protein 3 (RFRP3) was characterized (Hinuma et al., 2000; Yano et al., 2003; Kriegsfeld et al., 2006; Johnson et al., 2007; Ubuka et al., 2009). Like its avian counterpart, RFRP3 has also been localized to the median eminence and shown to inhibit gonadotropin release from the pituitary (Clarke et al., 2008). In addition to pituitary actions, there is also evidence that GnIH/RFRP3 can inhibit GnRH cell firing (Ducret et al., 2009; Wu et al., 2009b), suggesting there may also be hypothalamic actions of GnIH/RFRP3. This finding is supported by immunohistochemical data demonstrating GnIH/RFRP3 fibers in close contact with GnRH cell bodies in birds, rats, sheep, and non-human primates (Johnson et al., 2007; Smith et al., 2008, 2010a; Ubuka et al., 2008). In fact, results demonstrating a lack of hypophysiotropic effects of RFRP3 in the rat have lead to the hypothesis that RFRP3 action may be solely hypothalamic in this species (Anderson et al., 2009; Rizwan et al., 2009). More research is needed to understand the site of action of RFRP3 in the rat given contradictory evidence regarding (1) the presence of RFRP3 fibers in the external zone of the median eminence (Johnson et al., 2007; Rizwan et al., 2009; Bentley et al., 2010) and (2) in vivo actions of intracerebral ventricular RFRP3 administration on LH release (Johnson et al., 2007; Murakami et al., 2008; Anderson et al., 2009; Rizwan et al., 2009).

Given the inhibitory action of GnIH/RFRP3 on gonadotropin release, many studies have investigated the role of this peptide during conditions of GnRH suppression (Smith and Clarke, 2010; Clarke, 2011). In both birds and sheep GnIH/RFRP3 appears to be higher in the non-breeding season suggesting a potential role in seasonal regulation of reproductive function (Bentley et al., 2003; Smith et al., 2008; Clarke and Smith, 2010). GnIH/RFRP3 has also been shown to inhibit sexual behavior in birds and rats (Bentley et al., 2006; Johnson et al., 2007). Although GnIH/RFRP3 has been implicated in inhibited reproductive function, the role of this peptide in governing cyclic fluctuations of gonadotropins during ovarian cycling in mammals is still not well understood. Work in the rat found exogenous RFRP3 reduced c-Fos activity in GnRH and AVPV cells at the time of an induced-LH surge, but RFRP3 had no affect on basal pulsatile GnRH release (Anderson et al., 2009). In the hamster Fos activation is decreased in RFRP3 cells at the time of the LH surge (Gibson et al., 2008). Differential regulation of RFRP3 during the ovarian cycle was found in hamsters and monkeys, but in opposite directions. While RFRP3 was high during diestrus in the hamster (Gibson et al., 2008), nonhuman primates showed elevated levels immediately prior to the GnRH/LH surge (Smith et al., 2010a). The latter finding was surprising since high levels of RFRP3 would be expected to suppress GnRH/LH levels; therefore, it is possible RFRP3's role in ovarian cyclicity is not always strongly inhibitory.

Studies focusing on the reproductive aspects of the GnIH/RFRP3 system have also noted a potential role for
GnIH/RFRP3 in appetite regulation. Exogenous administration of $\mathrm{GnIH}$ in chicks was found to potently stimulate food intake, potentially through an opioid receptor system (Tachibana et al., 2005, 2008). RFRP3 was also found to stimulate food intake in rats, resulting in a doubling of food consumption during the photophase (Johnson et al., 2007; Murakami et al., 2008), consistent with the well established role of RF-amide related proteins and appetite regulation (Dockray, 2004). The evidence for a regulatory role of $\mathrm{GnIH} / \mathrm{RFRP} 3$ in reproduction and appetite suggests this neuropeptide may be important for integration of energy balance and reproductive function (Smith and Clarke, 2010; Clarke, 2011). The characteristics of inhibitory effects on reproductive function and stimulatory effects on food intake makes it tempting to hypothesize that RFRP3 may be upregulated during negative energy balance. If RFRP3 is elevated during negative energy balance it could work to both conserve energy output through inhibition of reproductive cycling and increase energy input through food intake. Future research will undoubtedly be aimed at answering this question. Additional future directions for $\mathrm{GnIH}$ research may be electrophysiological and anatomical studies to determine if RFRP3 has any direct influence on Kiss1 release, since fiber distribution analysis suggests RFRP3 terminals are in the region of both the AVPV and arcuate nucleus Kiss1 populations (Rizwan et al., 2009). Additionally, investigations using GnIH antagonists could determine whether blocking a potential negative energy balance-induced rise in GnIH/RFRP3 prevents inhibition of $\mathrm{GnRH}$ release.

\section{ALARIN}

Galanin-like peptide (GALP) has been previously linked to the integration of energy balance and reproduction (Krasnow et al., 2003; Kageyama et al., 2005; Lawrence and Fraley, 2010). Recent evidence suggests a splice variant of the GALP gene, termed alarin (Santic et al., 2006), may have a similar regulatory function. Alarin appears orexigenic in rodents since intracerebral ventricular injections of alarin result in a fivefold acute increase in food intake and increased body weight gain after chronic administration (Boughton et al., 2010; Van Der Kolk et al., 2010). Alarin has also been implicated in reproductive regulation due to its expression in sexually important nuclei such as the preoptic area and other hypothalamic regions including the arcuate nucleus (Eberhard et al., 2011). Furthermore, work in male rodents has found evidence that alarin may be stimulatory for LH release, potentially in a GnRH-dependent manner (Boughton et al., 2010; Van Der Kolk et al., 2010). Further research is needed to understand the role of alarin in regulation of reproductive function in females, since past studies have focused only on males. Future studies in females will also be important in determining whether steroid hormone environment affects the direction of alarin's regulatory action on LH release as it does for many other orexigenic neuropeptides (Crowley and Kalra, 1987; Pu et al., 1998).

The apparent stimulatory action of alarin on LH release observed in males is in contrast to the inhibitory effects found with most other orexigenic neuropeptides, such as NPY, MCH, and orexin (Kalra and Kalra, 1996; Pu et al., 1998; Tamura et al., 1999; Murray et al., 2000; Chiocchio et al., 2001; Kohsaka et al., 
2001; Small et al., 2003; Wu et al., 2009a). There is significant evidence that these well-studied orexigenic neuropeptides regulate $\mathrm{GnRH}$ release through direct projections to $\mathrm{GnRH}$ cell bodies ( $\mathrm{Li}$ et al., 1999b; Iqbal et al., 2001; Campbell et al., 2003; Small et al., 2003; Williamson-Hughes et al., 2005). Therefore, direct inhibitory effects on GnRH cells would be greatly enhanced during states of negative energy balance when their activities are upregulated (Xu et al., 2009a; Rondini et al., 2010; Smith et al., 2010b). However, it is unclear how alarin may influence $\mathrm{GnRH}$ regulation. One study found alarin-like immunoreactivity in the preoptic area (Eberhard et al., 2011), but it has not been examined whether this immunoreactivity is in close proximity to $\mathrm{GnRH}$ cell bodies. It is also unclear how alarin might be differentially regulated during negative energy balance, since orexigenic drive should be high while LH stimulation would be expected to be low. Future research may elucidate how alarin contributes to the integration of energy balance and reproductive function, and what if any role this neuropeptide has in negative energy balance-induced acyclicity.

\section{BRAINSTEM GLUCOSE-SENSING POPULATIONS}

Certain neuronal populations are capable of sensing metabolic status through changes in circulating glucose levels. This characteristic offers an attractive and relatively simple mechanism through which metabolic status may be acutely sensed in the brain and potentially relayed to reproductive circuits. One such glucose-sensing population exists in the ventrolateral medulla of the brainstem (for review see Ritter et al., 2006). Glucosedeprivation achieved with administration of 2-deoxy-D-glucose, a glucose molecule unable to undergo glycolysis, results in c-Fos activation in the catecholaminergic $\mathrm{A} 1 / \mathrm{C} 1$ subregion of the ventrolateral medulla (Ritter et al., 1998). To determine if the A1/C1 catecholamine neurons contributed to the reproductive inhibition associated with glucoprivation this population was ablated by injection of a conjugated dopamine-beta hydroxylase saporin toxin complex (I'Anson et al., 2003). Interestingly, when A1/C1 catecholamine neurons were destroyed this prevented 2-deoxyD-glucose-induced reproductive acyclicity, strongly implicating a role for this population in the integration of energy balance and reproductive function. Microdialysis during 2-deoxy-D-glucose administration revealed increases in noradrenaline release in the hypothalamus, and intervention to block this noradrenaline rise prevented inhibition of LH (Nagatani et al., 1996). In addition, it appears that noradrenaline's role in LH suppression is not specific to the 2-deoxy-D-glucose model of negative energy balance, given similar results were observed in fasting animals (Cagampang et al., 1992; Maeda et al., 1994). These studies suggest that increases in noradrenaline, potentially from the $\mathrm{A} 1 / \mathrm{C} 1$ subregion, during negative energy balance may be critical for inhibition of LH release. This inhibitory role for catecholamines, and noradrenaline specifically, on LH release is consistent with previous literature (Maeda et al., 1994; Tsukamura et al., 1994; Nagatani et al., 1996), and electrophysiological recordings as well as anatomical results suggest this inhibitory action may be exerted directly upon GnRH cells (Todman et al., 2005; Campbell and Herbison, 2007; Han and Herbison, 2008). However, noradrenaline is also stimulatory for $\mathrm{LH}$ release, and these contradictory regulatory influences are thought to be dependent on steroid hormone levels, with noradrenaline stimulatory for LH in the presence of high levels of estradiol and inhibitory in the presence of low levels of estradiol (Gallo and Drouva, 1979; Leung et al., 1982; Meyer and Goodman, 1985; Havern et al., 1991; Cagampang et al., 1992; Robinson and Kendrick, 1992; Herbison, 1997), as would be associated with negative energy balance.

In the lactation model of negative energy balance the A1 noradrenergic region was also found to have c-Fos activation in response to pup suckling (Li et al., 1999c). Pup suckling is strongly implicated in LH inhibition during lactation (Brogan et al., 1999; Smith and Grove, 2002; Smith et al., 2010b), once again supporting an inhibitory role for noradrenaline during negative energy balance. Noradrenergic neurons of A1 activated by the suckling stimulus were also found to project to the arcuate nucleus ( $\mathrm{Li}$ et al., 1999a). Contradictory evidence for A1 noradrenaline projections to GnRH cells exists, suggesting it is possible that an intermediary population may be involved in mediating noradrenaline's effects on GnRH (Wright and Jennes, 1993; Simonian et al., 1999; Campbell and Herbison, 2007). Given the projection to the arcuate nucleus, we sought to determine whether noradrenaline might regulate the upstream arcuate nucleus Kiss1/NKB population. Immunohistochemistry presented here demonstrates that arcuate nucleus Kiss1/NKB and AVPV Kiss1 neurons appear to have close appositions from DBH/NPY positive fibers (Figure 1). This finding indicates Kiss1 populations may receive regulatory inputs from brainstem catecholamine neurons, since this is the only known area where catecholamines and NPY are colocalized in the same neurons (Everitt et al., 1984; Bai et al., 1985). It remains to be confirmed whether brainstem catecholamine fibers contacting Kiss 1 cells are from the ventrolateral medulla A1 region and future tract-tracing studies will be aimed at defining the source of this catecholaminergic input.

\section{CONCLUSION}

It is clear that although leptin is undoubtedly involved in the regulation of reproductive and metabolic status, leptin's role in negative energy balance is likely permissive and not causative for

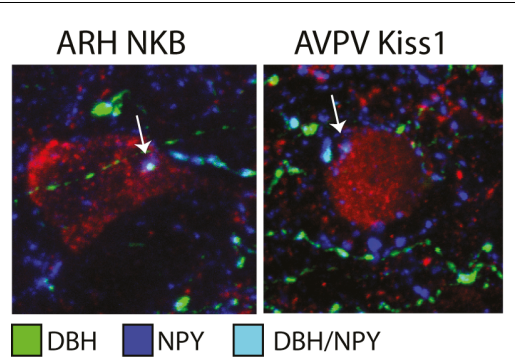

FIGURE 1 | Close appositions of brainstem catecholamine fibers on arcuate nucleus (ARH) NKB and AVPV Kiss1cells. Immunohistochemistry of colocalized NPY (AB1583, Millipore; 1:5000; blue) and dopamine-beta hydroxylase (MAB308, Millipore; 1:5000; green) fibers represents projections from brainstem catecholamine populations that coexpress NPY (for detailed methods see True et al., 2011a). Colocalized NPY/DBH fibers (light blue) were found in close contact with ARH NKB cells (3/61, a gift from Dr. Phillipe Ciofi; 1:4000; red, left photomicrograph) and AVPV Kiss1 cells (AB9754, Millipore; 1:1000; red, right photomicrograph). 


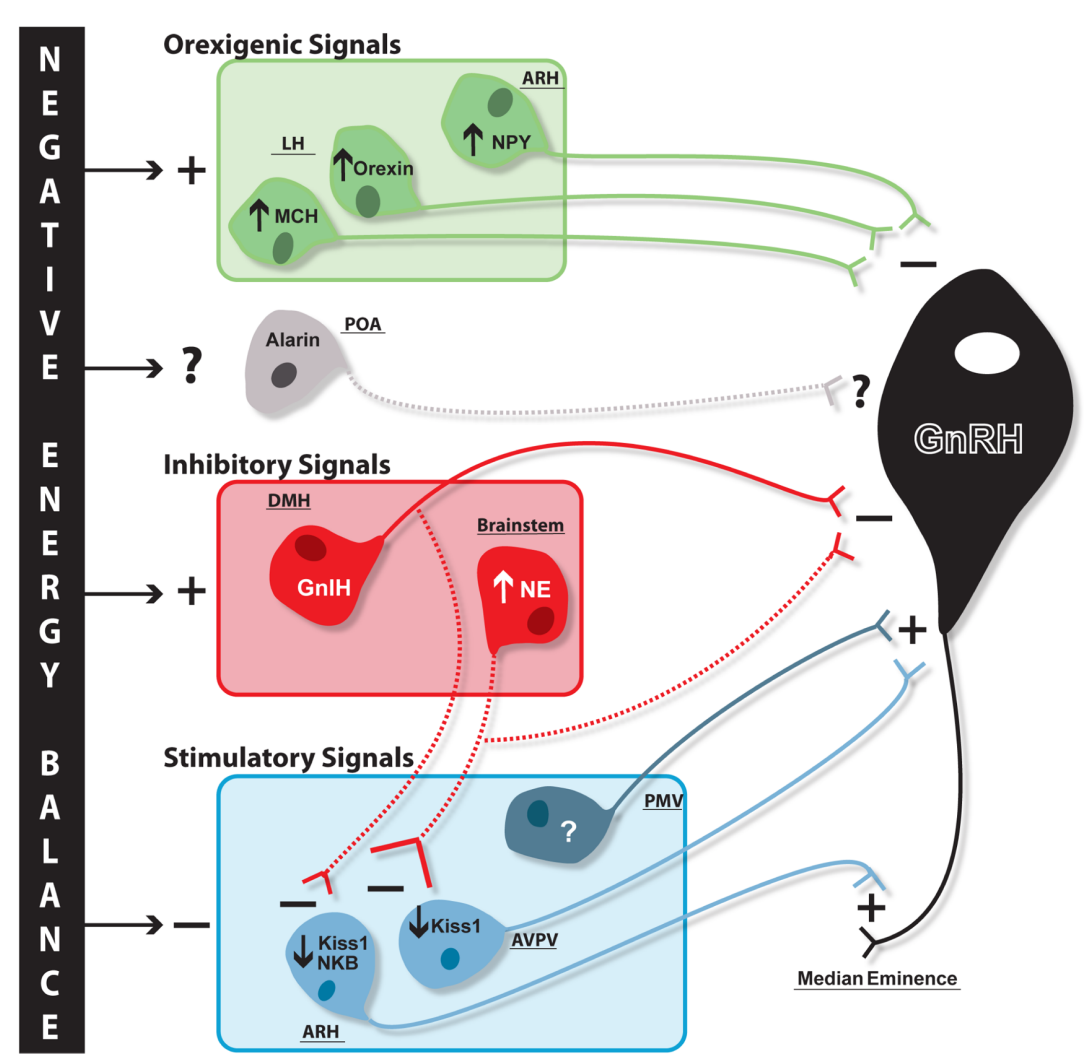

FIGURE 2 | Proposed schematic of negative energy balance-induced changes in reproductive and metabolic circuits contributing to $\mathbf{G n R H}$ inhibition. Negative energy balance results in differential regulation of systems both stimulatory and inhibitory for $\mathrm{GnRH}$ release. Orexigenic neuropeptides (green) melanin-concentrating hormone $(\mathrm{MCH})$ and orexin in the lateral hypothalamus (LH) and neuropeptide Y (NPY) in the arcuate nucleus ( $\mathrm{ARH}$ ) are all stimulated (plus sign) with negative energy balance and inhibit (minus sign) $\mathrm{GnRH}$ (black) release through direct regulation at cell bodies. It is unknown whether alarin is differentially regulated during negative energy balance, but it is proposed these neurons may also project to $\mathrm{GnRH}$ cell bodies (hypothesized regulatory influence and projections represented with dashed lines). Negative energy balance stimulates additional cell populations that are inhibitory for $\mathrm{GnRH}$ release (red), namely the dorsomedial hypothalamus (DMH) GnIH and brainstem noradrenaline (NE) populations. While $\mathrm{GnIH}$, and potentially brainstem NE, cells project to $\mathrm{GnRH}$ cell bodies, it is hypothesized these cells may also inhibit upstream stimulatory Kiss1 populations. ARH kisspeptin/neurokinin B (Kiss1/NKB) and anteroventral periventricular nucleus (AVPV) Kiss1 populations (blue), which stimulate $\mathrm{GnRH}$ terminals and cell bodies, respectively, are inhibited during negative energy balance. Negative energy balance is also proposed to inhibit an unknown stimulatory cell population in the ventral premammillary nucleus (PMV) which has direct projections to $\mathrm{GnRH}$ cell bodies. the severe inhibition of GnRH release. The finding that restoration of leptin to normal physiological levels does not restore $\mathrm{GnRH}$ release in multiple models of negative energy balance supports this conclusion. Given this evidence, the search continues for signals that may be critical for integrating reproductive and metabolic function. One obvious candidate not previously discussed here is the orexigenic gut hormone ghrelin, which has already been extensively reviewed for its potential role in the integration of energy balance and reproduction (Fernandez-Fernandez et al., 2006; Garcia et al., 2007; Tena-Sempere, 2008). Similar to leptin, ghrelin is a predominantly peripheral-derived hormone capable of sensing changes in metabolic state, but unlike leptin ghrelin is orexigenic and elevated during negative energy balance. Ghrelin has also been found to be inhibitory for $\mathrm{GnRH}$ release in several species (Tschop et al., 2000; Wren et al., 2000; Ariyasu et al., 2001; Furuta et al., 2001; Fernandez-Fernandez et al., 2004, 2005a,b; Vulliemoz et al., 2004; Iqbal et al., 2006). In looking beyond leptin, future research investigating the circuits and modes through which ghrelin regulates $\mathrm{GnRH}$ release may prove critical for our understanding of negative energy balance-induced reproductive dysfunction. One potential intermediary for ghrelin's actions on GnRH release may be Kiss1 (Forbes et al., 2009). Kiss1 has been strongly implicated in the integration of energy balance and reproduction given arcuate nucleus Kiss1/NKB and AVPV Kiss1 expression levels are low in various states of negative energy balance. Significantly, arcuate nucleus Kiss1/NKB and AVPV Kiss1 levels were also not restored with physiological leptin treatment during negative energy balance, and methods aimed at preventing negative energy balance-induced hyperghrelinemia may elucidate whether this rise in ghrelin is critical for Kiss 1 inhibition. Given the importance of the Kiss1 system for negative energy balance acycility, the search for other metabolic signals influencing this neuronal population is a leading research question in this field.

Gonadotropin-inhibitory hormone/RFRP3, alarin, and glucosesensing ventrolateral medulla neurons are just a few of the 
emerging candidates that have been linked to reproductive and metabolic regulation and as such may play a role in the integration of these systems. These three candidates are diverse in both their mechanism of metabolic sensing and their site of action in reproductive neuroendocrine circuits (Figure 2). GnIH/RFRP3 and noradrenergic ventrolateral medulla cells are both inhibitory signals for GnRH release that are increased during negative energy balance. While noradrenergic A1 cells are likely activated by low glucose levels, it is unclear how GnIH/RFRP3 might be upregulated during negative energy balance. However, once activated GnIH/RFRP3 cells likely contribute to increased orexigenic drive during negative energy balance, and it will be of interest to understand how GnIH may integrate with other well known metabolic/food intake systems of the hypothalamus, such as NPY, $\mathrm{MCH}$, and orexin, to contribute to this orexigenic drive. Although GnIH/RFRP3 and the A1 populations may both be inhibitory for $\mathrm{GnRH}$ release, there is evidence that they may differ in their site of action within the hypothalamic-pituitary-gonadal axis. There is strong evidence that GnIH/RFRP3 acts directly at GnRH cells. New data presented here suggests there is potential brainstem noradrenergic input to arcuate nucleus Kiss1/NKB and AVPV Kiss1 cells, and future research will be aimed at determining whether the source of these inputs is in fact the noradrenergic A1 population. GnIH/RFRP3 fibers are also found in the arcuate nucleus indicating that this population may regulate Kiss1/NKB as well, though more detailed histological research will be needed to test this hypothesis. Unlike $\mathrm{GnIH}$ and the A1 noradrenergic population, there is little research on the role of alarin for reproductive regulation during negative energy balance given how recently this neuropeptide was discovered. However, the limited amount of

\section{REFERENCES}

Ahima, R. S., Dushay, J., Flier, S. N., Prabakaran, D., and Flier, J. S. (1997). Leptin accelerates the onset of puberty in normal female mice. J. Clin. Invest. 99, 391-395.

Ahima, R. S., Prabakaran, D., Mantzoros, C., Qu, D., Lowell, B., Maratos-Flier, E., and Flier, J. S. (1996). Role of leptin in the neuroendocrine response to fasting. Nature 382, 250-252.

Aloi, J. A., Bergendahl, M., Iranmanesh, A., and Veldhuis, J. D. (1997). Pulsatile intravenous gonadotropin-releasing hormone administration averts fasting-induced hypogonadotropism and hypoandrogenemia in healthy, normal weight men. J. Clin. Endocrinol. Metab. 82, 1543-1548.

Anderson, G. M., Relf, H. L., Rizwan, M. Z., and Evans, J. J. (2009). Central and peripheral effects of RFamiderelated peptide- 3 on luteinizing hormone and prolactin secretion in rats. Endocrinology 150, 1834-1840.

Ariyasu, H., Takaya, K., Tagami, T., Ogawa, Y., Hosoda, K., Akamizu,
T., Suda, M., Koh, T., Natsui, K., Toyooka, S., Shirakami, G., Usui, T., Shimatsu, A., Doi, K., Hosoda, H., Kojima, M., Kangawa, K., and Nakao, K. (2001). Stomach is a major source of circulating ghrelin, and feeding state determines plasma ghrelin-like immunoreactivity levels in humans. J. Clin. Endocrinol. Metab. 86, 4753-4758. Pereira, A., Iqbal, J., Ogawa, S., Li, Q., and Clarke, I. J. (2010). Kisspeptin cells in the ewe brain respond to leptin and communicate with neuropeptide $\mathrm{Y}$ and proopiomelanocortin cells. Endocrinology 151, 2233-2243.

Bai, F. L., Yamano, M., Shiotani, Y., Emson, P. C., Smith, A. D., Powell, J. F., and Tohyama, M. (1985). An arcuato-paraventricular and -dorsomedial hypothalamic neuropeptide Y-containing system which lacks noradrenaline in the rat. Brain Res. 331, 172-175.

Barash, I. A., Cheung, C. C., Weigle, D. S., Ren, H., Kabigting, E. B., Kuijper, J. L., Clifton, D. K., and Steiner, R. A. (1996). Leptin is a metabolic signal to the reproductive
Backholer, K., Smith, J. T., Rao, A.,

research available on alarin suggests it may play a role in both food intake and reproductive regulation, much like its sistergene product, GALP. Research examining the effects of alarin on reproductive parameters in females will be a crucial next step in determining what role this neuropeptide might play in the larger neuroendocrine pathway, including the regulatory direction of alarin's effect on LH release, as well as its potential site of action.

As more and more candidates involved in both reproductive and metabolic regulatory systems emerge, it is becoming clear that there are likely multiple signals and mechanisms working in concert to tightly couple the regulation of these two critical physiological processes. More specifically, negative energy balance results in wide spread changes in the hypothalamus, including increases in numerous orexigenic neuropeptides known to regulate GnRH release, increases in signals inhibitory for reproduction, and decreases in signals excitatory for reproduction (Figure 2). With such a myriad of changes in these two regulatory systems, it is unlikely any one factor is solely responsible for the subsequent inhibition of GnRH release. Similarly, there may be many metabolic signals that are required to produce sustained $\mathrm{GnRH}$ inhibition, for example acute decreases in glucose levels, intermediary increases in the gut orexigenic hormone ghrelin, and long-term decreases in circulating leptin. The most beneficial work of the future will likely be those studies that attempt to understand how multiple signals work in concert to control GnRH release during negative energy balance.

\section{ACKNOWLEDGMENTS}

Supporting Grants: HD14643, U54 HD18185, RR00163, and U54 HD28934 (to the University of Virginia).

system. Endocrinology 137, 3144-3147.

Bentley, G. E., Jensen, J. P., Kaur, G. J., Wacker, D. W., Tsutsui, K. and Wingfield, J. C. (2006). Rapid inhibition of female sexual behavior by gonadotropin-inhibitory hormone (GnIH). Horm. Behav. 49, 550-555.

Bentley, G. E., Perfito, N., Ukena, K., Tsutsui, K., and Wingfield, J. C. (2003). Gonadotropin-inhibitory peptide in song sparrows (Melospiza melodia) in different reproductive conditions, and in house sparrows (Passer domesticus) relative to chicken-gonadotropin-releasing hormone. J. Neuroendocrinol. 15, 794-802.

Bentley, G. E., Tsutsui, K., and Kriegsfeld, L. J. (2010). Recent studies of gonadotropin-inhibitory hormone $(\mathrm{GnIH})$ in the mammalian hypothalamus, pituitary and gonads. Brain Res. 1364, 62-71.

Bergendahl, M., Perheentupa, A., and Huhtaniemi, I. (1991). Starvationinduced suppression of pituitarytesticular function in rats is reversed by pulsatile gonadotropin-releasing hormone substitution. Biol. Reprod. 44, 413-419.

Billings, H. J., Connors, J. M., Altman, S. N., Hileman, S. M., Holaskova, I., Lehman, M. N., McManus, C. J., Nestor, C. C., Jacobs, B. H., and Goodman, R. L. (2010). Neurokinin $B$ acts via the Neurokinin-3 receptor in the retrochiasmatic area to stimulate luteinizing hormone secretion in sheep. Endocrinology 151, 3836-3846.

Blache, D., Tellam, R. L., Chagas, L. M., Blackberry, M. A., Vercoe, P. E., and Martin, G. B. (2000). Level of nutrition affects leptin concentrations in plasma and cerebrospinal fluid in sheep. J. Endocrinol. 165, 625-637.

Bluher, S., and Mantzoros, C. S. (2007). Leptin in reproduction. Curr. Opin. Endocrinol. Diabetes Obes. 14, 458-464.

Boughton, C. K., Patterson, M., Bewick, G. A., Tadross, J. A., Gardiner, J. V., Beale, K. E., Chaudery, F., Hunter, G. Busbridge, M., Leavy, E. M., Ghatei, M. A., Bloom, S. R., and Murphy, K. G. (2010). Alarin stimulates food intake and gonadotrophin release in male rats. Br. J. Pharmacol. 161, 601-613. 
Brogan, R. S., Mitchell, S. E., Trayhurn, P., and Smith, M. S. (1999). Suppression of leptin during lactation: contribution of the suckling stimulus versus milk production. Endocrinology 140, 2621-2627.

Bronson, F. H. (1986). Food-restricted, prepubertal, female rats: rapid recovery of luteinizing hormone pulsing with excess food, and full recovery of pubertal development with gonadotropin-releasing hormone. Endocrinology 118 2483-2487.

Burke, M. C., Letts, P. A., Krajewski, S. J., and Rance, N. E. (2006). Coexpression of dynorphin and neurokinin B immunoreactivity in the rat hypothalamus: morphologic evidence of interrelated function within the arcuate nucleus. J. Comp. Neurol. 498, 712-726.

Cagampang, F. R., Ohkura, S., Tsukamura, H., Coen, C. W., Ota, K., and Maeda, K. (1992). Alpha 2adrenergic receptors are involved in the suppression of luteinizing hormone release during acute fasting in the ovariectomized estradiolprimed rats. Neuroendocrinology 56, 724-728.

Cameron, J. L., and Nosbisch, C. (1991). Suppression of pulsatile luteinizing hormone and testosterone secretion during short term food restriction in the adult male rhesus monkey (Macaca mulatta). Endocrinology 128, 1532-1540.

Campbell, R. E., Grove, K. L., and Smith, M. S. (2003). Gonadotropinreleasing hormone neurons coexpress orexin 1 receptor immunoreactivity and receive direct contacts by orexin fibers. Endocrinology 144, 1542-1548.

Campbell, R. E., and Herbison, A. E. (2007). Definition of brainstem afferents to gonadotropin-releasing hormone neurons in the mouse using conditional viral tract tracing. Endocrinology 148, 5884-5890.

Castellano, J. M., Bentsen, A. H., Mikkelsen, J. D., and Tena-Sempere, M. (2010). Kisspeptins: bridging energy homeostasis and reproduction. Brain Res. 1364, 129-138.

Castellano, J. M., Navarro, V. M., Fernandez-Fernandez, R., Nogueiras, R., Tovar, S., Roa, J., Vazquez, M. J., Vigo, E., Casanueva, F. F., Aguilar, E., Pinilla, L., Dieguez, C., and Tena-Sempere, M. (2005). Changes in hypothalamic KiSS-1 system and restoration of pubertal activation of the reproductive axis by kisspeptin in undernutrition. Endocrinology 146, 3917-3925.

Castellano, J. M., Navarro, V. M., Fernandez-Fernandez, R., Roa, J., Vigo, E., Pineda, R., Dieguez,
C., Aguilar, E., Pinilla, L., and Tena-Sempere, M. (2006). Expression of hypothalamic KiSS-1 system and rescue of defective gonadotropic responses by kisspeptin in streptozotocininduced diabetic male rats. Diabetes 55, 2602-2610.

Castellano, J. M., Roa, J., Luque, R. M., Dieguez, C., Aguilar, E., Pinilla, L., and Tena-Sempere, M. (2009). KiSS-1/kisspeptins and the metabolic control of reproduction: physiologic roles and putative physiopathological implications. Peptides 30, 139-145.

Chehab, F. F., Lim, M. E., and Lu, R. (1996). Correction of the sterility defect in homozygous obese female mice by treatment with the human recombinant leptin. Nat. Genet. 12, 318-320.

Chehab, F. F., Mounzih, K., Lu, R., and Lim, M. E. (1997). Early onset of reproductive function in normal female mice treated with leptin. Science 275, 88-90.

Chiocchio, S. R., Gallardo, M. G., Louzan, P., Gutnisky, V., and Tramezzani, J. H. (2001). Melanin-concentrating hormone stimulates the release of luteinizing hormone-releasing hormone and gonadotropins in the female rat acting at both median eminence and pituitary levels. Biol. Reprod. 64, 1466-1472.

Clarke, I. J. (2011). Control of GnRH secretion: one step back. Front. Neuroendocrinol. 32, 367-375.

Clarke, I. J., and Henry, B. A. (1999). Leptin and reproduction. Rev. Reprod. 4, 48-55.

Clarke, I. J., Sari, I. P., Qi, Y., Smith, J. T., Parkington, H. C., Ubuka, T., Iqbal, J., Li, Q., Tilbrook, A., Morgan, K., Pawson, A. J., Tsutsui, K., Millar, R. P., and Bentley, G. E. (2008). Potent action of RFamide-related peptide-3 on pituitary gonadotropes indicative of a hypophysiotropic role in the negative regulation of gonadotropin secretion. Endocrinology 149, 5811-5821.

Clarke, I. J., and Smith, J. T. (2010). The role of kisspeptin and gonadotropin inhibitory hormone (GnIH) in the seasonality of reproduction in sheep. Soc. Reprod. Fertil. Suppl. 67, 159-169.

Clarkson, J., d'Anglemont de Tassigny, X., Moreno, A. S., Colledge, W. H., and Herbison, A. E. (2008). Kisspeptin-GPR54 signaling is essential for preovulatory gonadotropin-releasing hormone neuron activation and the luteinizing hormone surge. J. Neurosci. 28, 8691-8697.
Clarkson, J., and Herbison, A. E. (2009). Oestrogen, kisspeptin, GPR54 and the pre-ovulatory luteinising hormone surge. J. Neuroendocrinol. 21, 305-311.

Clement, K., Vaisse, C., Lahlou, N., Cabrol, S., Pelloux, V., Cassuto, D., Gourmelen, M., Dina, C., Chambaz, J., Lacorte, J. M., Basdevant, A., Bougneres, P., Lebouc, Y., Froguel, P., and Guy-Grand, B. (1998). A mutation in the human leptin receptor gene causes obesity and pituitary dysfunction. Nature 392 398-401.

Corander, M. P., Challis, B. G., Thompson, E. L., Jovanovic, Z., Loraine Tung, Y. C., Rimmington, D., Huhtaniemi, I. T., Murphy, K. G., Topaloglu, A. K., Yeo, G. S., O’Rahilly, S., Dhillo, W. S., Semple, R. K., and Coll, A. P. (2010). The effects of neurokinin B upon gonadotropin release in male rodents. J. Neuroendocrinol. 22, 181-187.

Crowley, W. R., and Kalra, S. P. (1987) Neuropeptide Y stimulates the release of luteinizing hormonereleasing hormone from medial basal hypothalamus in vitro: $\bmod$ ulation by ovarian hormones. Neuroendocrinology 46, 97-103.

Cunningham, M. J., Clifton, D. K. and Steiner, R. A. (1999). Leptin's actions on the reproductive axis: perspectives and mechanisms. Biol. Reprod. 60, 216-222.

Danzer, S. C., Price, R. O., McMullen, N. T., and Rance, N. E. (1999). Sex steroid modulation of neurokinin $B$ gene expression in the arcuate nucleus of adult male rats. Brain Res. Mol. Brain Res. 66, 200-204.

de Roux, N., Genin, E., Carel, J. C. Matsuda, F., Chaussain, J. L., and Milgrom, E. (2003). Hypogonadotropic hypogonadism due to loss of function of the KiSS1-derived peptide receptor GPR54. Proc. Natl. Acad. Sci. U.S.A. 100, 10972-10976.

Dockray, G. J. (2004). The expanding family of RFamide peptides and their effects on feeding behaviour. Exp. Physiol. 89, 229-235.

Donato, J. Jr., Cravo, R. M., Frazao, R., Gautron, L., Scott, M. M., Lachey, J., Castro, I. A., Margatho, L. O., Lee, S., Lee, C., Richardson, J. A., Friedman, J., Chua, S. Jr., Coppari, R., Zigman, J. M., Elmquist, J. K., and Elias, C. F. (2011). Leptin's effect on puberty in mice is relayed by the ventral premammillary nucleus and does not require signaling in Kiss1 neurons. J. Clin. Invest. 121, 355-368.

Donato, J. Jr., Silva, R. J., Sita, L. V., Lee, S., Lee, C., Lacchini, S., Bittencourt, J. C., Franci, C. R., Canteras, N. S., and Elias, C. F. (2009). The ventral premammillary nucleus links fasting-induced changes in leptin levels and coordinated luteinizing hormone secretion. J. Neurosci. 29, 5240-5250.

Ducret, E., Anderson, G. M., and Herbison, A. E. (2009). RFamiderelated peptide-3, a mammalian gonadotropin-inhibitory hormone ortholog, regulates gonadotropinreleasing hormone neuron firing in the mouse. Endocrinology 150, 2799-2804.

Dumalska, I., Wu, M., Morozova, E., Liu, R., van den Pol, A., and Alreja, M. (2008). Excitatory effects of the puberty-initiating peptide kisspeptin and group I metabotropic glutamate receptor agonists differentiate two distinct subpopulations of gonadotropin-releasing hormone neurons. J. Neurosci. 28, 8003-8013.

Dungan, H. M., Clifton, D. K., and Steiner, R. A. (2006). Minireview: kisspeptin neurons as central processors in the regulation of gonadotropin-releasing hormone secretion. Endocrinology 147, 1154-1158.

Eberhard, N., Mayer, C., Santic, R., Navio, R. P., Wagner, A., Bauer, H. C., Sperk, G., Boehm, U., and Kofler, B. (2011). Distribution of alarin immunoreactivity in the mouse brain. J. Mol. Neurosci. PMID: 21647713. [Epub ahead of print].

Everitt, B. J., Hokfelt, T., Terenius, L., Tatemoto, K., Mutt, V., and Goldstein, M. (1984). Differential co-existence of neuropeptide $\mathrm{Y}$ (NPY)-like immunoreactivity with catecholamines in the central nervous system of the rat. Neuroscience 11, 443-462.

Fernandez-Fernandez, R., Martini, A. C., Navarro, V. M., Castellano, J. M., Dieguez, C., Aguilar, E., Pinilla, L. and Tena-Sempere, M. (2006). Novel signals for the integration of energy balance and reproduction. Mol. Cell. Endocrinol. 254-255, 127-132.

Fernandez-Fernandez, R., Navarro, V. M., Barreiro, M. L., Vigo, E. M., Tovar, S., Sirotkin, A. V., Casanueva F. F., Aguilar, E., Dieguez, C., Pinilla, L., and Tena-Sempere, M. (2005a). Effects of chronic hyperghrelinemia on puberty onset and pregnancy outcome in the rat. Endocrinology 146, 3018-3025.

Fernandez-Fernandez, R., TenaSempere, M., Navarro, V. M., Barreiro, M. L., Castellano, J. M., Aguilar, E., and Pinilla, L. (2005b). Effects of ghrelin upon gonadotropin-releasing hormone and gonadotropin secretion in adult female rats: in vivo and in vitro studies. Neuroendocrinology 82, 245-255. 
Fernandez-Fernandez, R., TenaSempere, M., Aguilar, E., and Pinilla, L. (2004). Ghrelin effects on gonadotropin secretion in male and female rats. Neurosci. Lett. 362, 103-107.

Forbes, S., Li, X. F., Kinsey-Jones, J., and O'Byrne, K. (2009). Effects of ghrelin on Kisspeptin mRNA expression in the hypothalamic medial preoptic area and pulsatile luteinising hormone secretion in the female rat. Neurosci. Lett. 460, 143-147.

Furuta, M., Funabashi, T., and Kimura, F. (2001). Intracerebroventricular administration of ghrelin rapidly suppresses pulsatile luteinizing hormone secretion in ovariectomized rats. Biochem. Biophys. Res. Commun. 288, 780-785.

Gallo, R. V., and Drouva, S. V. (1979). Effect of intraventricular infusion of catecholamines on luteinizing hormone release in ovariectomized and ovariectomized, steroid-primed rats. Neuroendocrinology 29, 149-162.

Garcia, M. C., Lopez, M., Alvarez, C. V., Casanueva, F., Tena-Sempere, M., and Dieguez, C. (2007). Role of ghrelin in reproduction. Reproduction 133, 531-540.

Gibson, E. M., Humber, S. A., Jain, S., Williams, W. P. III., Zhao, S., Bentley, G. E., Tsutsui, K., and Kriegsfeld, L. J. (2008). Alterations in RFamide-related peptide expression are coordinated with the preovulatory luteinizing hormone surge. Endocrinology 149, 4958-4969.

Goodman, R. L., Lehman, M. N., Smith, J. T., Coolen, L. M., de Oliveira, C. V., Jafarzadehshirazi, M. R., Pereira, A., Iqbal, J., Caraty, A., Ciofi, P., and Clarke, I. J. (2007). Kisspeptin neurons in the arcuate nucleus of the ewe express both dynorphin A and neurokinin B. Endocrinology 148, 5752-5760.

Goubillon, M. L., Forsdike, R. A., Robinson, J. E., Ciofi, P., Caraty, A., and Herbison, A. E. (2000). Identification of neurokinin B-expressing neurons as an highly estrogenreceptive, sexually dimorphic cell group in the ovine arcuate nucleus. Endocrinology 141, 4218-4225.

Gruaz, N. M., Lalaoui, M., Pierroz, D. D., Englaro, P., Sizonenko, P. C., Blum, W. F., and Aubert, M. L. (1998). Chronic administration of leptin into the lateral ventricle induces sexual maturation in severely foodrestricted female rats. J. Neuroendocrinol. 10, 627-633.

Han, S. K., and Herbison, A. E. (2008). Norepinephrine suppresses gonadotropin-releasing hormone neuron excitability in the adult mouse. Endocrinology 149, 1129-1135.
Havern, R. L., Whisnant, C. S., and Goodman, R. L. (1991). Hypothalamic sites of catecholamine inhibition of luteinizing hormone in the anestrous ewe. Biol. Reprod. 44, 476-482.

Herbison, A. E. (1997). Noradrenergic regulation of cyclic $\mathrm{GnRH}$ secretion. Rev. Reprod. 2, 1-6.

Hill, J. W., Elmquist, J. K., and Elias, C. F. (2008). Hypothalamic pathways linking energy balance and reproduction. Am. J. Physiol. Endocrinol. Metab. 294, E827-E832.

Hinuma, S., Shintani, Y., Fukusumi, S., Iijima, N., Matsumoto, Y., Hosoya, M., Fujii, R., Watanabe, T., Kikuchi, K., Terao, Y., Yano, T., Yamamoto, T., Kawamata, Y., Habata, Y., Asada, M., Kitada, C., Kurokawa, T., Onda, H., Nishimura, O., Tanaka, M., Ibata, Y., and Fujino, M. (2000). New neuropeptides containing carboxyterminal RFamide and their receptor in mammals. Nat. Cell Biol. 2, 703-708.

Hughes, A. M., Everitt, B. J., and Herbert, J. (1988). The effects of simultaneous or separate infusions of some pro-opiomelanocortinderived peptides (beta-endorphin, melanocyte stimulating hormone, and corticotrophin-like intermediate polypeptide) and their acetylated derivatives upon sexual and ingestive behaviour of male rats. Neuroscience 27, 689-698.

I'Anson, H., Sundling, L. A., Roland, S. M., and Ritter, S. (2003). Immunotoxic destruction of distinct catecholaminergic neuron populations disrupts the reproductive response to glucoprivation in female rats. Endocrinology 144, 4325-4331.

Imura, H., Kato, Y., Nakai, Y., Nakao, K., Tanaka, I., Jingami, H., Koh, T., Yoshimasa, T., Tsukada, T., Suda, M., Sakamoto, M., Morii, N., Takahashi, H., Tojo, K., and Sugawara, A. (1985). Endogenous opioids and related peptides: from molecular biology to clinical medicine. The Sir Henry Dale lecture for 1985. J. Endocrinol. 107, 147-157.

Ingalls, A. M., Dickie, M. M., and Snell, G. D. (1950). Obese, a new mutation in the house mouse. J. Hered. $41,317-318$.

Iqbal, J., Kurose, Y., Canny, B., and Clarke, I. J. (2006). Effects of central infusion of ghrelin on food intake and plasma levels of growth hormone, luteinizing hormone, prolactin, and cortisol secretion in sheep. Endocrinology 147, 510-519.

Iqbal, J., Pompolo, S., Sakurai, T., and Clarke, I. J. (2001). Evidence that orexin-containing neurones provide direct input to gonadotropinreleasing hormone neurones in the ovine hypothalamus. J. Neuroendocrinol. 13, 1033-1041.

Johnson, M. A., Tsutsui, K., and Fraley, G. S. (2007). Rat RFamide-related peptide-3 stimulates GH secretion, inhibits LH secretion, and has variable effects on sex behavior in the adult male rat. Horm. Behav. 51, 171-180.

Kageyama, H., Takenoya, F., Kita T., Hori, T., Guan, J. L., and Shioda, S. (2005). Galanin-like peptide in the brain: effects on feeding, energy metabolism and reproduction. Regul. Pept. 126, 21-26.

Kalra, S. P., and Kalra, P. S. (1996). Nutritional infertility: the role of the interconnected hypothalamic neuropeptide Y-galanin-opioid network. Front. Neuroendocrinol. 17, 371-401.

Kile, J. P., Alexander, B. M., Moss, G. E., Hallford, D. M., and Nett, T. M. (1991). Gonadotropin-releasing hormone overrides the negative effect of reduced dietary energy on gonadotropin synthesis and secretion in ewes. Endocrinology 128, 843-849.

Kim, M. S., Rossi, M., Abusnana, S. Sunter, D., Morgan, D. G., Small, C. J., Edwards, C. M., Heath, M. M., Stanley, S. A., Seal, L. J., Bhatti, J. R., Smith, D. M., Ghatei, M. A., and Bloom, S. R. (2000). Hypothalamic localization of the feeding effect of agouti-related peptide and alpha-melanocyte-stimulating hormone. Diabetes 49, 177-182.

Kinoshita, F., Nakai, Y., Katakami, H., and Imura, H. (1982). Suppressive effect of dynorphin-(1-13) on luteinizing hormone release in conscious castrated rats. Life Sci. 30, 1915-1919.

Kohsaka, A., Watanobe, H., Kakizaki, Y. Suda, T., and Schioth, H. B. (2001) A significant participation of orexinA, a potent orexigenic peptide, in the preovulatory luteinizing hormone and prolactin surges in the rat. Brain Res. 898, 166-170.

Kotani, M., Detheux, M., Vandenbogaerde, A., Communi, D., Vanderwinden, J. M., Le Poul, E. Brezillon, S., Tyldesley, R., SuarezHuerta, N., Vandeput, F., Blanpain, C., Schiffmann, S. N., Vassart, G. and Parmentier, M. (2001). The metastasis suppressor gene KiSS1 encodes kisspeptins, the natural ligands of the orphan $\mathrm{G}$ proteincoupled receptor GPR54. J. Biol. Chem. 276, 34631-34636.

Krajewski, S. J., Anderson, M. J., IlesShih, L., Chen, K. J., Urbanski, H. F., and Rance, N. E. (2005).
Morphologic evidence that neurokinin B modulates gonadotropinreleasing hormone secretion via neurokinin 3 receptors in the rat median eminence. J. Comp. Neurol. 489, 372-386.

Krasnow, S. M., Fraley, G. S., Schuh, S. M., Baumgartner, J. W., Clifton, D. K., and Steiner, R. A. (2003). A role for galanin-like peptide in the integration of feeding, body weight regulation, and reproduction in the mouse. Endocrinology 144, 813-822.

Kriegsfeld, L. J., Mei, D. F., Bentley, G. E., Ubuka, T., Mason, A. O., Inoue, K. Ukena, K., Tsutsui, K., and Silver, R. (2006). Identification and characterization of a gonadotropin-inhibitory system in the brains of mammals. Proc. Natl. Acad. Sci. U.S.A. 103, 2410-2415.

Lawrence, C., and Fraley, G. S. (2010). Galanin-like peptide (GALP) is a hypothalamic regulator of energy homeostasis and reproduction. Front. Neuroendocrinol. 32, 1-9.

Leadem, C. A., and Kalra, S. P. (1985). Effects of endogenous opioid peptides and opiates on luteinizing hormone and prolactin secretion in ovariectomized rats. Neuroendocrinology 41, 342-352.

Leshan, R. L., Louis, G. W., Jo, Y. H., Rhodes, C. J., Munzberg, H., and Myers, M. G. Jr. (2009). Direct innervation of GnRH neurons by metabolic- and sexual odorantsensing leptin receptor neurons in the hypothalamic ventral premammillary nucleus. J. Neurosci. 29, 3138-3147.

Leung, P. C., Arendash, G. W., Whitmoyer, D. I., Gorski, R. A., and Sawyer, C. H. (1982). Differential effects of central adrenoceptor agonists on luteinizing hormone release. Neuroendocrinology 34, 207-214.

Li, C., Chen, P., and Smith, M. S. (1999a). Identification of neuronal input to the arcuate nucleus (ARH) activated during lactation: implications in the activation of neuropeptide Y neurons. Brain Res. 824, 267-276.

Li, C., Chen, P., and Smith, M. S. (1999b). Morphological evidence for direct interaction between arcuate nucleus neuropeptide $\mathrm{Y}$ (NPY) neurons and gonadotropinreleasing hormone neurons and the possible involvement of NPY Y1 receptors. Endocrinology 140, 5382-5390.

Li, C., Chen, P., and Smith, M. S. (1999c). Neural populations in the rat forebrain and brainstem activated by the suckling stimulus as demonstrated by cFos expression. Neuroscience 94, 117-129. 
Louis, G. W., Greenwald-Yarnell, M., Phillips, R., Coolen, L. M., Lehman, M. N., and Myers, M. G. Jr. (2011). Molecular mapping of the neural pathways linking leptin to the neuroendocrine reproductive axis. Endocrinology 152, 2302-2310.

Luque, R. M., Kineman, R. D., and TenaSempere, M. (2007). Regulation of hypothalamic expression of KiSS-1 and GPR54 genes by metabolic factors: analyses using mouse models and a cell line. Endocrinology 148, 4601-4611.

Maeda, K., Cagampang, F. R., Coen, C. W., and Tsukamura, H. (1994). Involvement of the catecholaminergic input to the paraventricular nucleus and of corticotropinreleasing hormone in the fastinginduced suppression of luteinizing hormone release in female rats. Endocrinology 134, 1718-1722.

Maffei, M., Halaas, J., Ravussin, E., Pratley, R. E., Lee, G. H., Zhang, Y., Fei, H., Kim, S., Lallone, R., Ranganathan, S., Kern, P. A., and Friedman, J. M. (1995). Leptin levels in human and rodent: measurement of plasma leptin and ob RNA in obese and weight-reduced subjects. Nat. Med. 1, 1155-1161.

Mantzoros, C. S., Flier, J. S., and Rogol, A. D. (1997). A longitudinal assessment of hormonal and physical alterations during normal puberty in boys. V. Rising leptin levels may signal the onset of puberty. J. Clin. Endocrinol. Metab. 82, 1066-1070.

Meyer, S. L., and Goodman, R. L. (1985). Neurotransmitters involved in mediating the steroid-dependent suppression of pulsatile luteinizing hormone secretion in anestrous ewes: effects of receptor antagonists. Endocrinology 116, 2054-2061.

Muir, A. I., Chamberlain, L., Elshourbagy, N. A., Michalovich, D., Moore, D. J., Calamari, A., Szekeres, P. G., Sarau, H. M., Chambers, J. K., Murdock, P., Steplewski, K., Shabon, U., Miller, J. E., Middleton, S. E., Darker, J. G., Larminie, C. G., Wilson, S., Bergsma, D. J., Emson, P., Faull, R., Philpott, K. L., and Harrison, D. C. (2001). AXOR12, a novel human $\mathrm{G}$ protein-coupled receptor, activated by the peptide KiSS-1. J. Biol. Chem. 276, 28969-28975.

Murakami, M., Matsuzaki, T., Iwasa, T., Yasui, T., Irahara, M., Osugi, T., and Tsutsui, K. (2008). Hypophysiotropic role of RFamide-related peptide-3 in the inhibition of LH secretion in female rats. $J$. Endocrinol. 199, 105-112.

Murray, J. F., Adan, R. A., Walker, R., Baker, B. I., Thody, A. J., Nijenhuis, W. A., Yukitake, J., and Wilson,
C. A. (2000). Melanin-concentrating hormone, melanocortin receptors and regulation of luteinizing hormone release. J. Neuroendocrinol. 12, 217-223.

Nagatani, S., Guthikonda, P., Thompson, R. C., Tsukamura, H., Maeda, K. I., and Foster, D. L. (1998). Evidence for GnRH regulation by leptin: leptin administration prevents reduced pulsatile $\mathrm{LH}$ secretion during fasting. Neuroendocrinology 67, 370-376.

Nagatani, S., Tsukamura, H., Murahashi, K., Bucholtz, D. C., Foster, D. L., and Maeda, K. (1996). Paraventricular norepinephrine release mediates glucoprivic suppression of pulsatile luteinizing hormone secretion. Endocrinology 137, 3183-3186.

Nagatani, S., Zeng, Y., Keisler, D. H., Foster, D. L., and Jaffe, C. A. (2000). Leptin regulates pulsatile luteinizing hormone and growth hormone secretion in the sheep. Endocrinology 141, 3965-3975.

Navarro, V. M., Castellano, J. M., Fernandez-Fernandez, R., Barreiro, M. L., Roa, J., Sanchez-Criado, J. E., Aguilar, E., Dieguez, C., Pinilla, L., and Tena-Sempere, M. (2004). Developmental and hormonally regulated messenger ribonucleic acid expression of KiSS-1 and its putative receptor, GPR54, in rat hypothalamus and potent luteinizing hormone-releasing activity of KiSS-1 peptide. Endocrinology 145, 4565-4574.

Navarro, V. M., Castellano, J. M., McConkey, S. M., Pineda, R., RuizPino, F., Pinilla, L., Clifton, D. K., Tena-Sempere, M., and Steiner, R. A. (2011). Interactions between kisspeptin and neurokinin $\mathrm{B}$ in the control of GnRH secretion in the female rat. Am. J. Physiol. Endocrinol. Metab. 300, E202-E210.

Navarro, V. M., Gottsch, M. L., Chavkin, C., Okamura, H., Clifton, D. K., and Steiner, R. A. (2009). Regulation of gonadotropinreleasing hormone secretion by kisspeptin/dynorphin/neurokinin $\mathrm{B}$ neurons in the arcuate nucleus of the mouse. J. Neurosci. 29, 11859-11866.

Ohtaki, T., Shintani, Y., Honda, S., Matsumoto, H., Hori, A., Kanehashi, K., Terao, Y., Kumano, S., Takatsu, Y., Masuda, Y., Ishibashi, Y., Watanabe, T., Asada, M., Yamada, T., Suenaga, M., Kitada, C., Usuki, S., Kurokawa, T., Onda, H., Nishimura, O., and Fujino, M. (2001). Metastasis suppressor gene KiSS-1 encodes peptide ligand of a G-protein-coupled receptor. Nature 411, 613-617.
Patterson, C. M., Leshan, R. L., Jones, J. C., and Myers, M. G. Jr. (2011). Molecular mapping of mouse brain regions innervated by leptin receptor-expressing cells. Brain Res. 1378, 18-28.

Phillips, M. S., Liu, Q., Hammond, H. A., Dugan, V., Hey, P. J., Caskey, C. J., and Hess, J. F. (1996). Leptin receptor missense mutation in the fatty Zucker rat. Nat. Genet. 13, 18-19.

Pillon, D., Caraty, A., Fabre-Nys, C., and Bruneau, G. (2003). Short-term effect of oestradiol on neurokinin $B$ mRNA expression in the infundibular nucleus of ewes. J. Neuroendocrinol. 15, 749-753.

Plant, T. M., and Durrant, A. R. (1997). Circulating leptin does not appear to provide a signal for triggering the initiation of puberty in the male rhesus monkey (Macaca mulatta). Endocrinology 138, 4505-4508.

Popa, S. M., Clifton, D. K., and Steiner, R. A. (2008). The role of kisspeptins and GPR54 in the neuroendocrine regulation of reproduction. Annu. Rev. Physiol. 70, 213-238.

Pu, S., Jain, M. R., Kalra, P. S., and Kalra, S. P. (1998). Orexins, a novel family of hypothalamic neuropeptides, modulate pituitary luteinizing hormone secretion in an ovarian steroid-dependent manner. Regul. Pept. 78, 133-136.

Qiu, J., Fang, Y., Bosch, M. A., Ronnekleiv, O. K., and Kelly, M. J. (2011). Guinea pig kisspeptin neurons are depolarized by leptin via activation of TRPC channels. Endocrinology 152, 1503-1514.

Quennell, J. H., Howell, C. S., Roa, J., Augustine, R. A., Grattan, D. R. and Anderson, G. M. (2011). Leptin deficiency and diet-induced obesity reduce hypothalamic kisspeptin expression in mice. Endocrinology 152, 1541-1550.

Quennell, J. H., Mulligan, A. C., Tups, A., Liu, X., Phipps, S. J., Kemp, C. J., Herbison, A. E., Grattan, D. R., and Anderson, G. M. (2009). Leptin indirectly regulates gonadotropinreleasing hormone neuronal function. Endocrinology 150, 2805-2812.

Ramaswamy, S., Seminara, S. B., Ali, B., Ciofi, P., Amin, N. A., and Plant, T. M. (2010). Neurokinin B stimulates GnRH release in the male monkey (Macaca mulatta) and is colocalized with kisspeptin in the arcuate nucleus. Endocrinology 151, 4494-4503.

Rance, N. E. (2009). Menopause and the human hypothalamus: evidence for the role of kisspeptin/neurokinin B neurons in the regulation of estrogen negative feedback. Peptides 30, 111-122.
Rance, N. E., and Young, W. S. III. (1991). Hypertrophy and increased gene expression of neurons containing neurokinin-B and substance-P messenger ribonucleic acids in the hypothalami of postmenopausal women. Endocrinology 128, 2239-2247.

Ritter, S., Dinh, T. T., and Li, A. J. (2006). Hindbrain catecholamine neurons control multiple glucoregulatory responses. Physiol. Behav. 89, 490-500.

Ritter, S., Llewellyn-Smith, I., and Dinh, T. T. (1998). Subgroups of hindbrain catecholamine neurons are selectively activated by 2-deoxy-Dglucose induced metabolic challenge. Brain Res. 805, 41-54.

Rizwan, M. Z., Porteous, R., Herbison, A. E., and Anderson, G. M. (2009). Cells expressing RFamiderelated peptide- $1 / 3$, the mammalian gonadotropin-inhibitory hormone orthologs, are not hypophysiotropic neuroendocrine neurons in the rat. Endocrinology 150, 1413-1420.

Roa, J., Aguilar, E., Dieguez, C., Pinilla, L., and Tena-Sempere, M. (2008). New frontiers in kisspeptin/GPR54 physiology as fundamental gatekeepers of reproductive function. Front. Neuroendocrinol. 29, 48-69.

Robinson, J. E., and Kendrick, K. M. (1992). Inhibition of luteinizing hormone secretion in the ewe by progesterone: associated changes in the release of gamma-aminobutyric acid and noradrenaline in the preoptic area as measured by intracranial microdialysis. J. Neuroendocrinol. 4, 231-236.

Rondini, T. A., Donato, J. Jr., Rodrigues Bde, C., Bittencourt, J. C., and Elias, C. F. (2010). Chemical identity and connections of medial preoptic area neurons expressing melaninconcentrating hormone during lactation. J. Chem. Neuroanat. 39, 51-62.

Sahu, A., and Kalra, S. P. (1992). Effects of tachykinins on luteinizing hormone release in female rats: potent inhibitory action of neuropeptide K. Endocrinology 130, 1571-1577.

Saiduddin, S., Bray, G. A., York, D. A., and Swerdloff, R. S. (1973). Reproductive function in the genetically obese "fatty" rat. Endocrinology 93, 1251-1256.

Sandoval-Guzman, T., and Rance, N. E. (2004). Central injection of senktide, an NK3 receptor agonist, or neuropeptide $\mathrm{Y}$ inhibits $\mathrm{LH}$ secretion and induces different patterns of Fos expression in the rat hypothalamus. Brain Res. 1026, 307-312. 
Santic, R., Fenninger, K., Graf, K., Schneider, R., Hauser-Kronberger, C., Schilling, F. H., Kogner, P., Ratschek, M., Jones, N., Sperl, W., and Kofler, B. (2006). Gangliocytes in neuroblastic tumors express alarin, a novel peptide derived by differential splicing of the galanin-like peptide gene. J. Mol. Neurosci. 29, 145-152.

Schioth, H. B., and Watanobe, H. (2002). Melanocortins and reproduction. Brain Res. Brain Res. Rev. $38,340-350$.

Schulz, R., Wilhelm, A., Pirke, K. M., Gramsch, C., and Herz, A. (1981). Beta-endorphin and dynorphin control serum luteinizing hormone level in immature female rats. Nature 294, 757-759.

Seminara, S. B., Messager, S., Chatzidaki, E. E., Thresher, R. R., Acierno, J. S. Jr., Shagoury, J. K., Bo-Abbas, Y., Kuohung, W., Schwinof, K. M., Hendrick, A. G., Zahn, D., Dixon, J., Kaiser, U. B., Slaugenhaupt, S. A., Gusella, J. F., O’Rahilly, S., Carlton, M. B., Crowley, W. F. Jr., Aparicio, S. A., and Colledge, W. H. (2003). The GPR54 gene as a regulator of puberty. N. Engl. J. Med. 349, 1614-1627.

Simonian, S. X., Spratt, D. P., and Herbison, A. E. (1999). Identification and characterization of estrogen receptor alpha-containing neurons projecting to the vicinity of the gonadotropin-releasing hormone perikarya in the rostral preoptic area of the rat. J. Comp. Neurol. $411,346-358$.

Small, C. J., Goubillon, M. L., Murray, J. F., Siddiqui, A., Grimshaw, S. E., Young, H., Sivanesan, V., Kalamatianos, T., Kennedy, A. R., Coen, C. W., Bloom, S. R., and Wilson, C. A. (2003). Central orexin A has site-specific effects on luteinizing hormone release in female rats. Endocrinology 144, 3225-3236.

Smith, J. T., Acohido, B. V., Clifton, D. K., and Steiner, R. A. (2006a). KiSS-1 neurones are direct targets for leptin in the ob/ob mouse. J. Neuroendocrinol. 18, 298-303.

Smith, J. T., Popa, S. M., Clifton, D. K., Hoffman, G. E., and Steiner, R. A. (2006b). Kiss1 neurons in the forebrain as central processors for generating the preovulatory luteinizing hormone surge. J. Neurosci. 26, 6687-6694.

Smith, J. T., and Clarke, I. J. (2010). Gonadotropin inhibitory hormone function in mammals. Trends Endocrinol. Metab. 21, 255-260.
Smith, J. T., Coolen, L. M., Kriegsfeld, L. J., Sari, I. P., Jaafarzadehshirazi, M. R., Maltby, M., Bateman, K., Goodman, R. L., Tilbrook, A. J., Ubuka, T., Bentley, G. E., Clarke, I. J., and Lehman, M. N. (2008). Variation in kisspeptin and RFamide-related peptide (RFRP) expression and terminal connections to gonadotropinreleasing hormone neurons in the brain: a novel medium for seasonal breeding in the sheep. Endocrinology 149, 5770-5782.

Smith, J. T., Cunningham, M. J., Rissman, E. F., Clifton, D. K., and Steiner, R. A. (2005a). Regulation of Kiss 1 gene expression in the brain of the female mouse. Endocrinology 146, 3686-3692.

Smith, J. T., Dungan, H. M., Stoll, E. A., Gottsch, M. L., Braun, R. E., Eacker, S. M., Clifton, D. K., and Steiner, R. A. (2005b). Differential regulation of KiSS-1 mRNA expression by sex steroids in the brain of the male mouse. Endocrinology 146, 2976-2984.

Smith, J. T., Shahab, M., Pereira, A., Pau, K. Y., and Clarke, I. J. (2010a). Hypothalamic expression of KISS1 and gonadotropin inhibitory hormone genes during the menstrual cycle of a nonhuman primate. Biol. Reprod. 83 568-577.

Smith, M. S., True, C., and Grove, K. L. (2010b). The neuroendocrine basis of lactation-induced suppression of GnRH: role of kisspeptin and leptin. Brain Res. 1364, 139-152.

Smith, M. S., and Grove, K. L. (2002). Integration of the regulation of reproductive function and energy balance: lactation as a model. Front. Neuroendocrinol. 23, 225-256.

Strobel, A., Issad, T., Camoin, L., Ozata, M., and Strosberg, A. D. (1998). A leptin missense mutation associated with hypogonadism and morbid obesity. Nat. Genet. 18, 213-215.

Swerdloff, R. S., Batt, R. A., and Bray, G. A. (1976). Reproductive hormonal function in the genetically obese (ob/ob) mouse. Endocrinology 98, 1359-1364.

Szymanski, L. A., Schneider, J. E., Friedman, M. I., Ji, H., Kurose, Y., Blache, D., Rao, A., Dunshea, F. R., and Clarke, I. J. (2007). Changes in insulin, glucose and ketone bodies, but not leptin or body fat content precede restoration of luteinising hormone secretion in ewes. $J$. Neuroendocrinol. 19, 449-460.

Tachibana, T., Masuda, N., Tsutsui, K., Ukena, K., and Ueda, H. (2008). The orexigenic effect of $\mathrm{GnIH}$ is mediated by central opioid receptors in chicks. Comp. Biochem. Physiol. Part A Mol. Integr. Physiol. 150, 21-25.

Tachibana, T., Sato, M., Takahashi, H., Ukena, K., Tsutsui, K., and Furuse, M. (2005). Gonadotropininhibiting hormone stimulates feeding behavior in chicks. Brain Res. 1050, 94-100.

Tamura, T., Irahara, M., Tezuka, M., Kiyokawa, M., and Aono, T. (1999). Orexins, orexigenic hypothalamic neuropeptides, suppress the pulsatile secretion of luteinizing hormone in ovariectomized female rats. Biochem. Biophys. Res. Commun. 264, 759-762.

Tena-Sempere, M. (2007). Roles of ghrelin and leptin in the control of reproductive function. Neuroendocrinology 86, 229-241.

Tena-Sempere, M. (2008). Ghrelin as a pleotrophic modulator of gonadal function and reproduction. Nat. Clin. Pract. Endocrinol. Metab. 4 666-674.

Thompson, E. L., Patterson, M., Murphy, K. G., Smith, K. L., Dhillo, W. S. Todd, J. F., Ghatei, M. A., and Bloom, S. R. (2004). Central and peripheral administration of kisspeptin10 stimulates the hypothalamicpituitary-gonadal axis. J. Neuroendocrinol. 16, 850-858.

Todd, B. J., Ladyman, S. R., and Grattan, D. R. (2003). Suppression of pulsatile luteinizing hormone secretion but not luteinizing hormone surge in leptin resistant obese Zucker rats. J. Neuroendocrinol. 15, 61-68.

Todman, M. G., Han, S. K., and Herbison, A. E. (2005). Profiling neurotransmitter receptor expression in mouse gonadotropin-releasing hormone neurons using green fluorescent protein-promoter transgenics and microarrays. Neuroscience 132 , 703-712.

Topaloglu, A. K., Reimann, F., Guclu, M., Yalin, A. S., Kotan, L. D., Porter, K. M., Serin, A., Mungan, N. O., Cook, J. R., Ozbek, M. N., Imamoglu, S., Akalin, N. S., Yuksel, B., O'Rahilly, S. and Semple, R. K. (2009). TAC3 and TACR3 mutations in familial hypogonadotropic hypogonadism reveal a key role for Neurokinin B in the central control of reproduction. Nat. Genet. 41, 354-358.

True, C., Kirigiti, M., Ciofi, P., Grove, K. L., and Smith, M. S. (2011a). Characterisation of arcuate nucleus kisspeptin/neurokinin B neuronal projections and regulation during lactation in the rat. J. Neuroendocrinol 23, 52-64.
True, C., Kirigiti, M. A., Kievit, P., Grove, K. L., and Susan Smith, M. (2011b). Leptin is not the critical signal for kisspeptin or luteinising hormone restoration during exit from negative energy balance. J. Neuroendocrinol. doi: 10.1111/j.13652826.2011.02144.x. [Epub ahead of print].

Tschop, M., Smiley, D. L., and Heiman, M. L. (2000). Ghrelin induces adiposity in rodents. Nature 407, 908-913.

Tsujii, S., and Bray, G. A. (1989). Acetylation alters the feeding response to MSH and beta-endorphin. Brain Res. Bull. 23, 165-169.

Tsukamura, H., Nagatani, S., Cagampang, F. R., Kawakami, S., and Maeda, K. (1994). Corticotropinreleasing hormone mediates suppression of pulsatile luteinizing hormone secretion induced by activation of alpha-adrenergic receptors in the paraventricular nucleus in female rats. Endocrinology 134, 1460-1466.

Tsutsui, K., Saigoh, E., Ukena, K., Teranishi, H., Fujisawa, Y., Kikuchi, M. Ishii, S., and Sharp, P. J. (2000). A novel avian hypothalamic peptide inhibiting gonadotropin release. Biochem. Biophys. Res. Commun. 275, 661-667.

Ubuka, T., Kim, S., Huang, Y. C., Reid, J., Jiang, J., Osugi, T., Chowdhury, V. S., Tsutsui, K., and Bentley, G. E. (2008). Gonadotropin-inhibitory hormone neurons interact directly with gonadotropin-releasing hormoneI and -II neurons in European starling brain. Endocrinology 149, 268-278.

Ubuka, T., Morgan, K., Pawson, A. J., Osugi, T., Chowdhury, V. S. Minakata, H., Tsutsui, K., Millar, R. P., and Bentley, G. E. (2009). Identification of human GnIH homologs, RFRP-1 and RFRP-3, and the cognate receptor, GPR147 in the human hypothalamic pituitary axis. PLoS ONE 4, e8400. doi:10.1371/journal.pone. 0008400

Van Der Kolk, N., Madison, F. N., Mohr, M., Eberhard, N., Kofler, B., and Fraley, G. S. (2010). Alarin stimulates food intake in male rats and LH secretion in castrated male rats. Neuropeptides 44, 333-340.

Vulliemoz, N. R., Xiao, E., Xia-Zhang, L. Germond, M., Rivier, J., and Ferin, M. (2004). Decrease in luteinizing hormone pulse frequency during a five-hour peripheral ghrelin infusion in the ovariectomized rhesus monkey. J. Clin. Endocrinol. Metab. 89, 5718-5723. 
Wakabayashi, Y., Nakada, T., Murata, K., Ohkura, S., Mogi, K., Navarro, V. M., Clifton, D. K., Mori, Y., Tsukamura, H., Maeda, K., Steiner, R. A., and Okamura, H. (2010). Neurokinin B and dynorphin $\mathrm{A}$ in kisspeptin neurons of the arcuate nucleus participate in generation of periodic oscillation of neural activity driving pulsatile gonadotropin-releasing hormone secretion in the goat. J. Neurosci. 30, 3124-3132.

Watanobe, H. (2002). Leptin directly acts within the hypothalamus to stimulate gonadotropin-releasing hormone secretion in vivo in rats. J. Physiol. (Lond.) 545(Pt 1), 255-268.

Welt, C. K., Chan, J. L., Bullen, J., Murphy, R., Smith, P., DePaoli, A. M., Karalis, A., and Mantzoros, C. S. (2004). Recombinant human leptin in women with hypothalamic amenorrhea. N. Engl. J. Med. 351, 987-997.

Williamson-Hughes, P. S., Grove, K. L., and Smith, M. S. (2005). Melanin concentrating hormone $(\mathrm{MCH})$ : a novel neural pathway for regulation of GnRH neurons. Brain Res. 1041, 117-124.

Wren, A. M., Small, C. J., Ward, H. L., Murphy, K. G., Dakin, C. L., Taheri, S., Kennedy,
A. R., Roberts, G. H., Morgan, D. G., Ghatei, M. A., and Bloom, S. R. (2000). The novel hypothalamic peptide ghrelin stimulates food intake and growth hormone secretion. Endocrinology 141, 4325-4328.

Wright, D. E., and Jennes, L. (1993). Origin of noradrenergic projections to $\mathrm{GnRH}$ perikarya-containing areas in the medial septum-diagonal band and preoptic area. Brain Res. 621, 272-278.

Wu, M., Dumalska, I., Morozova, E., van den Pol, A., and Alreja, M. (2009a). Melanin-concentrating hormone directly inhibits $\mathrm{GnRH}$ neurons and blocks kisspeptin activation, linking energy balance to reproduction. Proc. Natl. Acad. Sci. U.S.A. 106, 17217-17222.

Wu, M., Dumalska, I., Morozova, E., van den Pol, A. N., and Alreja, M. (2009b). Gonadotropin inhibitory hormone inhibits basal forebrain vGluT2-gonadotropinreleasing hormone neurons via a direct postsynaptic mechanism. J. Physiol. (Lond.) 587(Pt 7), 1401-1411.

Xu, J., Kirigiti, M. A., Cowley, M. A., Grove, K. L., and Smith, M. S. (2009a). Suppression of basal spontaneous gonadotropin-releasing hormone neuronal activity during lactation: role of inhibitory effects of neuropeptide Y. Endocrinology $150,333-340$.

Xu, J., Kirigiti, M. A., Grove, K. L., and Smith, M. S. (2009b). Regulation of food intake and gonadotropin-releasing hormone/luteinizing hormone during lactation: role of insulin and leptin. Endocrinology 150, 4231-4240.

Yamada, S., Uenoyama, Y., Kinoshita, M., Iwata, K., Takase, K., Matsui, H., Adachi, S., Inoue, K., Maeda, K. I., and Tsukamura, H. (2007). Inhibition of metastin (kisspeptin54)-GPR54 signaling in the arcuate nucleus-median eminence region during lactation in rats. Endocrinology 148, 2226-2232.

Yano, T., Iijima, N., Kakihara, K., Hinuma, S., Tanaka, M., and Ibata, Y. (2003). Localization and neuronal response of RFamide related peptides in the rat central nervous system. Brain Res. 982, 156-167.

Yu, W. H., Kimura, M., Walczewska, A., Karanth, S., and McCann, S. M. (1997). Role of leptin in hypothalamic-pituitary function. Proc. Natl. Acad. Sci. U.S.A. 94 1023-1028.
Zucker, L. M., and Zucker, T. F. (1961). Fatty, a new mutation in the rat. $J$ Hered. 52, 275-278.

Conflict of Interest Statement: The authors declare that the research was conducted in the absence of any commercial or financial relationships that could be construed as a potential conflict of interest.

Received: 30 August 2011; paper pending published: 21 September 2011; accepted: 29 September 2011; published online: 17 October 2011.

Citation: True C, Grove KL and Smith MS (2011) Beyond leptin: emerging candidates for the integration of metabolic and reproductive function during negative energy balance. Front. Endocrin. 2:53. doi: 10.3389/fendo.2011.00053

This article was submitted to Frontiers in Systems and Translational Endocrinology, a specialty of Frontiers in Endocrinology.

Copyright (c) 2011 True, Grove and Smith. This is an open-access article subject to a non-exclusive license between the authors and Frontiers Media SA, which permits use, distribution and reproduction in other forums, provided the original authors and source are credited and other Frontiers conditions are complied with. 